\title{
A saját tudás túlértékelésének tendenciája utánpótláskorú labdarúgók körében
}

\section{The tendency to overestimate one's own skills among young football players}

\author{
GOTTFRIED P. \\ Sportközgazdász MSC szakos hallgató, Debreceni Egyetem Gazdaságtudományi Kar, Vezetés- és \\ Szervezéstudományi Intézet, Emberi Erőforrás Menedzsment Tanszék \\ gottfriedpeter93@gmail.com
}

\begin{abstract}
Absztrakt
A mai sportban egyre nagyobb hangsúlyt fektetnek a fizikai állapot mellett a mentális felkészitésre is. A sportpszichológia meghatározó szerepet tölt be az egyéni és csapatsportágakban egyaránt. A sportolókat tekintve az egyik legfontosabb tényezö az, hogy megfelelö önértékeléssel rendelkezzenek, mivel ez a képesség jelentös mértékben befolyásolhatja az adott játékos teljesitményét. Kutatásom fö célkitüzése az volt, hogy labdarúgáshoz kapcsolódó feladatokon keresztül megvizsgáljam az önértékelési sajátosságokat utánpótláskorú labdarúgók körében. A gyakorlatok között volt a ,,dekázás”, labdapassz tornapadra, valamint a szlalom labdavezetést követö cél elérése. Hipotézisem szerint a gyerekek a feladatok elvégzése elött hajlamosnak mutatkoznak teljesitményük felülbecslésére.
\end{abstract}

Kutatásom során primer adatgyüjtést alkalmaztam. Az általam használt statisztikai elemzési módszer az egymintás t-teszt volt. Az elvégzett egymintás t-tesztek alapján megállapitottam, hogy a dekázási feladatban az alulbecslés volt jellemzö (ami ellentmond a hipotézisnek), mig a labdapassz és a szlalom feladatokban összességében felülbecsülték teljesitményüket a gyerekek (e két feladatnál megerösithetjük a hipotézist).

Kulcsszavak: Önértékelés, Teljesitmény, Utánpótláskorú labdarúgók, Sportpszichológia Abstract

In today's sport the mental preparation's role is emerging in addition to physical training Sports psychology is being implemented and applied widely both in invidiual and team sports. From the athletes perspective one of the most important factor is that they have the right and valid self-knowledge as their performance is highly affected by this input. The main objective of my research was to reveal the self assessment attributes among the young football players. The children performed three tasks during the research; juggling, passing on gymnastics bench and then reaching the finish line after dribbling of slalom were shown. My hypotesis is that the children tend to overestimate their performance and skills before performing tasks.

I've been used primary data collection during my research. The used applied analytical method was the one sample t-test; based on this method, we can say that the underestimation have had a higher rate when measuring juggling (which contradict to the hypotesis) while the children overestimated their performance in the slalom and the passing tasks (in these two tasks we can confirm the hypotesis).

Keywords: Self-esteem, Performance, Junior footballers, Sport psychology

\section{JEL Kód: Z29}

\section{Bevezetés}

Az önértékelés, mint fogalom a szakirodalomban több értelmezésben is jelen van. Az általam használt megközelítésben az önértékelés arra utal, hogy az emberek a saját teljesítményükre vonatkozóan, itéletet hoznak az általuk elért várható eredményre (Boud-Falchikov, 1989). A pszichológiában az önértékelés a személyiség összetett építőeleme, magában foglalja az élet eltérő területeiről elsajátított ismereteket. Így van ez az oktatás és a sport területén is. Az önértékelési képesség viszonylag állandónak mondható, de az életkorral változhat (Sallay et al., 2014). Több kutatás alapján megállapították, hogy az önértékelés gyerekkorban jobb, mint serdülőkorban, majd felnőtt korban javuló 
tendenciát mutat és időskorra láthatóan újra csökken ez a tulajdonság (Robins-Trzesniewsk,2005). Saját teljesítményünk értékelése hozzájárul a tanulási folyamatokhoz, képesek leszünk felmérni azon képességeinket, amelyek segítenek az adott helyzetben megfelelő döntést hozni. Az ideális értékelés az, amely megfelel a jelen szükségleteinek és segít feltárni azokat a képességeket, amely egy adott egyén jövőbeni tanulmányi szükségleteihez nélkülözhetetlen. A tervezett és strukturált önértékelési tevékenységek lehetővé teszik a kapcsolódó készségek fejlődését (Conroy et al., 2008).

Témámban az utánpótláskorú labdarúgók körét emelem ki, rájuk vonatkozóan fogom az önértékelés és a teljesítmény kapcsolatát vizsgálni. Önértékelési szempontból kiemelt szerepet játszik a sport és a sporttal kapcsolatos tevékenységek a gyerekek életében. A sportoló gyerekek azt képzelhetik, hogy az önértékelési képességük attól függ, hogy mennyire tudnak jó teljesítményt és eredményt elérni. A gyerekek a sportolás közben már az elején azzal találkoznak, hogy ha sikert akarnak elérni akkor mindenképpen győzniük kell. Az adott helyzetben viszont ez az önértékelés veszélyes is lehet a gyerekek életében, hiszen a sportban elért eredményei befolyásolhatják az önértékelési képességüket. Az énkép, mint fogalom jelentős szerepet képvisel az önértékelés folyamatában. Az énkép a saját személyiségünk mentális kifejezését foglalja magában, mely az általunk meghatározott jellemző sajátosságainkra vonatkozik. A gyerekkori énkép kialakulásában nagy szerepet játszanak a szülők. A szülőkre ebből a szempontból jelentős felelősség hárul, hiszen ez az időszak határozza meg a gyerek jövőbeli énképét (Orosz, 2010). Fontos tényező, hogy a gyerek a sportban elért énképét nem tudja elválasztani az élet többi területétől. Tapasztalatok alapján a sportolók gyakran esnek ebbe a hibába. Több esetben is előfordul, hogy hajlamosak a sportban elért énképét asszociálni a valódi énképükhöz. Az adott helyzetben ez azért veszélyes, mert a sportban elért esetleges kudarc után azt hiszi a gyerek, hogy az élet más területén is hasonló akadályokba fog ütközni, amiket nem tud teljesíteni. Ellenkező helyzetben is igaz, amikor is a sportban sikert ér el és ezáltal azt gondolja, hogy minden másban is sikeres lesz (Kovács-Nagy, 2015). Az említett esetekben fontos tényező, hogy a sportoló a sikert akarjae vagy a kudarcot szándékozik elkerülni. Sportpszichológiai szempontból ezek meghatározó faktorok. Az a sportoló, aki a sikerért küzd, képes megállapítani, hogy most azért ért el sikert mert megfelelö energiát mozgósított ennek érdekében, és amennyiben vesztesként jött ki, akkor azt azzal magyarázza, hogy ebben az esetben nem nyújtott elegendőt a győzelem eléréséhez. A kudarc kerülő sportoló szempontjából az a probléma, hogy az esteleges győzelem kapujában sem veszélyeztet, inkább olyan célokat akar teljesíteni, amit könnyen teljesíthet. A kudarc kerülő sportolók ezt azért teszik, hogy megelőzzék a kudarc során kialakult negatív visszajelzést. A gyerekek kudarc elkerülő viselkedései lehetnek kisebb sérülések kitalálása, illetve edzések, versenyek gyakori lemondása, (Gyömbér et al., 2016). Az esetleges gyenge teljesítmény megelőzése abból fakad, hogy ezek a sportolók alapvetően úgy érzik, hogy nem rendelkeznek megfelelő képességekkel és általában negatív előzményekkel rendelkeznek, illetve alacsony az önértékelési szintjük is (Gyömbér-Kovács, 2018).

A sportban a teljesítmények túlértékelésével kapcsolatban, fizikai és szellemi sport területén is kutattak. Fizikai sportban golfjátékosok között végeztek el vizsgálatot. Az analízisben két golfhoz kötődő technikai feladatot kellett végrehajtaniuk a játékosoknak, illetve volt egy teszt, ami a golf szabályainak ismeretét mérte fel. A játékosoknak a feladatok előtt kellett megjósolniuk teljesítményüket. Az első feladatban 2,5 méterről kellett eltalálni a kitüzött célt 20 lehetőségből. Ebben a feladatban észszerüen becsülték meg eredményeiket a vizsgálatban szereplő sportolók. A másik feladat lényege azonos volt, viszont a cél jelen eseteben 17,5 méterre helyezkedett el, amire szintén 20 lehetőségük volt a golfozóknak. A feladat elején, a játékosok előrejelzése eltért az előző feladattól. A sportolók felülbecsülték a teljesítményüket. A golffal kapcsolatos szabályismereti tesztben szintén túlértékelték eredményeiket a játékosok (Fogarty-Else,2011). Szellemi sport területén a teljesítmények túlértékelésének lehetséges jelenlétét, sakkjátékosok körében vizsgálták meg. A kutatásban utánpótláskorú játékosok és szüleik vettek részt. A vizsgálat során a gyerekek, szüleik ellen kellett, hogy játszanak és a játszma előtt meg kellett becsülniük az eredményt. A kutatás végén azt a következtetést vonták le, hogy a szülök hajlamosak voltak a teljesítményük túlértékelésére, míg a gyerekek pontosabban tudták megbecsülni a mérkőzések végső kimenetelét (Horgan,1992).

Önértékelési szempontból az utánpótlás játékosoknál kiemelten fontos, hogy az adott sportoló objektíven tudja megítélni saját teljesítményét, ami a fejlődésének egyik fontos faktora. Célom az volt, hogy a teljesítmények túlértékelési tendenciáját vizsgáljam meg, utánpótláskorú labdarúgók körében. A 
kutatás alapján kiderülhet, hogy a labdarúgók hajlamosak-e az egyes gyakorlati feladatoknál a teljesítményük túlértékelésére.

\section{Anyag és módszer}

Az adatok felvételére 2018 szeptemberében és októberében került sor, a Debrecen-Józsán elhelyezkedő sportpályán. A pályát a Józsa Sportegyesület használja. Az egyesület fó profilja a labdarúgó utánpótlás oktatása, ennek szervezése. A kutatás szempontjából releváns tényező, hogy a klub amatör szinten müködik. A vizsgálatot tekintve ez azért is fontos, mivel a vizsgálatban szereplő gyerekek a szabadidejük hasznos elöltése érdekében vesznek részt az edzéseken, nincs eredménykényszer és olyan teljesítményi elvárások, mint az akadémiai vagy más professzionálisan müködő egyesületek keretein belül.

A kutatáshoz szükséges feladatok lebonyolítását a Józsa Sportegyesületben tevékenykedő edzők segítségével végeztem el. A feladatok lényegét előzetesen ismertettem az edzőkkel, valamint több alkalommal a gyakorlatban is bemutattam azokat. Az edzők tájékoztatása mellett fontosnak tartottam, hogy az egyesület játékosait is felvilágosítsam arról, hogy az elvégzett feladatok milyen célt szolgálnak. A gyakorlati feladatok elvégzése során, mivel gyerekekről van szó, a megfelelő adatok kialakulásához figyelembe kellett venni, hogy motiváljuk őket, mert ellenkező esetben a feladatokat nem a saját tudásuknak megfelelően végezték volna el. Az ügyességi feladatok a gyerekek által is ismertek voltak, így ez megkönnyítette a gyakorlás folyamatát is. Az edzők számára biztosítottam egy értékelő adatlapot. $\mathrm{Az}$ adatlap egyik oldalán a gyakorlatok elött becsült teljesítmény állt, amit a gyerekek töltöttek ki, a másik oldalán pedig a tényleges eredményt az edzők jegyezték fel. A feladatok közé tartozott a „dekázás”, ami egy technikai mozdulatsor. Cél az volt, hogy a játékosok minél többször tudják végrehajtani a gyakorlatot, az edzők által kijelölt területen belül. A második gyakorlat a labdapassz volt tornapad segítségével. A játékosok számára 30 másodperc állt rendelkezésre, ez idő alatt kellett elérni minél több pontos passzt. Az utolsó feladat pedig a szlalom labdavezetést követő cél elérése volt. A jelző bóják közötti szlalom labdavezetés után, szintén bójákkal kijelölt területre kellett rúgni a labdát, amire 10 lehetőségük volt a gyerekeknek. A kutatásban négy korosztály vett részt, az U11, U14, U16 és az U19-es csapat játékosai. A játékosok kiválasztása során arra törekedtem, hogy minden korosztályban lehetőleg azonos számú gyerek végezze el a feladatokat. A vizsgálat alkalmával összességében 70 játékos hajtotta végre a gyakorlatokat, ebből 64 játékos adatait tudtam feldolgozni.

A kutatásomhoz felhasznált adatokat sztenderdizáltam, ami megbízhatóbb eredményeket alakít ki. A vizsgálat során az egymintás $t$-tesztet használtam fel. Az egymintás $t$-teszt segítségével láthatóvá vált, hogy a becslési hibák jelentősen különböznek-e a nullától, az elöjel alapján pedig arra tudtam következtetni, hogy alul vagy felülbecslés történt. Az előjeles hibákat úgy számítottam ki, hogy a játékosok által becsült értékből kivontam a tényleges értéket.

\section{Eredmények}

Eredményeim ismertetését a gyerekek által elvégzett dekázás, labdapassz és szlalom feladatok szerint mutatom be az alul- és felülbecslés mértékét, amelyet az egymintás $t$-teszt alapján állapítottam meg. Az elemzés kiemelt célja a felülbecslési tendencia bemutatása a három gyakorlati feladat alapján. A feladatok után kapott eredményeket korosztályokra bontva és az összes korosztály együttes teljesítményét tekintve analizáltam.

\subsection{A dekázás feladatának felülbecslési tendenciája}

Elsőként korosztályokra bontva mutatom be a dekázás után kapott eredményeimet az egymintás $t$ teszt elvégzése után kapott adatok alapján. A táblázatok a kutatásban szereplő korosztályok előjeles becslési hibáit szemléltetik. 
1. táblázat: A dekázás feladat elöjeles becslési hibái, korosztályokra bontva

Table 1: Self-assessment errors in the juggle task, divided into age groups

\begin{tabular}{|c|c|c|c|}
\hline Elöjeles becslési hiba & $\boldsymbol{N}$ & Átlag & Szórás \\
\hline Dekázás U11 & 16 & $-6,000$ & 17,080 \\
\hline Dekázás U14 & 16 & $-0,490$ & 0,862 \\
\hline Dekázás U16 & 16 & $-6,575$ & 0,734 \\
\hline Dekázás U19 & 16 & $-0,380$ & 13,306 \\
\hline
\end{tabular}

Forrás: Saját szerkesztés

2. táblázat: A dekázás feladat elöjeles hibái, korosztályokra bontva

Table 2: Self-assessment errors in the juggle task, divided into age groups

\begin{tabular}{|c|c|c|c|c|}
\hline \multirow{2}{*}{ Előjeles becslési hiba dekázás } & \multirow[b]{2}{*}{$t$} & \multirow[b]{2}{*}{$p$} & \multicolumn{2}{|c|}{ 95\%-os konfidencia-intervallum } \\
\hline & & & Alsó korlát & Felső korlát \\
\hline U11 & $-1,405$ & 0,180 & $-15,100$ & 3,100 \\
\hline U14 & $-2,275$ & 0,038 & $-0,950$ & $-0,031$ \\
\hline U16 & $-3,582$ & 0,003 & $-1,049$ & $-0,266$ \\
\hline U19 & $-0,113$ & 0,912 & $-7,470$ & 6,720 \\
\hline
\end{tabular}

Forrás: Saját szerkesztés. Megjegyzések: $N=16$ minden csoportban, $t=$ egymintás $t$-teszt (a tesztérték a nulla) $p<0,01 ; p<0,05$

Az 1. és 2. táblázatban az átlag alapján, ami -6,000, úgy tünhet, hogy átlagosan alulbecslés történt. A becslési hibák szignifikancia szintje 0,180, (nagyobb, mint 0,05), tehát nincs szignifikáns különbség, így abban nem lehetünk biztosak, hogy az eredmény eltér a nullától. Ennek alapján nem tudjuk megállapítani, hogy az U11-es korosztályban valóban több alábecslés történt a dekázás becslése során.

Az egymintás $t$-teszt alapján az átlag -0,490, amely 1. és 2. táblázat szerint megállapítható, hogy a dekázás feladatban az U14-es korosztályban többségben alábecsülték a teljesítményüket. A feltevést igazolja az is, hogy a szignifikancia szint 0,038 (kisebb, mint 0,05), tehát szignifikáns különbség van, ami által kijelenthető, hogy biztos nem nulla. A vizsgált korosztályban ezek alapján a teljesítményükre vonatkozóan, az alulbecslés volt jellemző.

Az U16-os korosztályban a dekázás illetően szintén alulbecslés figyelhető meg az 1. és 2. számú táblázatban található eredmények szerint. Az átlagos becslés -6,575, ebben az esetben a negatív előjel utal az alulbecslésre, a szignifikancia szint 0,003 tehát szignifikáns különbség merült fel, így biztos, hogy az átlag nem nulla. Kijelenthető az eredmények által, hogy az U16-os korosztályban az alulbecslésre voltak hajlamosak a dekázás feladatában.

Az ifjúsági csapat (U19) dekázásihoz kapcsolódó becslésének vizsgálatakor is megfigyelhető a 1 . és 2. számú táblázatban, a negatív előjeles átlag, ami -0,380, viszont a szignifikancia szint 0,912 , ami nem jelent szignifikáns különbséget, így nem lehetünk benne biztosak, hogy az átlag nem nulla. Ebben az esetben nem tudjuk statisztikai szempontból igazolni, hogy az U19-es korosztályban inkább hajlamosak magukat alulértékelni a dekázási feladatot megelőzően.

\subsection{A labdapassz feladat felülbecslési tendenciája}

3. táblázat: A labdapassz feladat elöjeles hibái, korosztályokra bontva Table3: Self-assessment errors in the passing task, divided into age groups

\begin{tabular}{|c|c|c|c|}
\hline Elöjeles becslési hiba & $\boldsymbol{N}$ & Átlag & Szórás \\
\hline Labdapassz U11 & 16 & 0,694 & 0,697 \\
\hline Labdapassz U14 & 16 & 0,001 & 1,001 \\
\hline Labdapassz U16 & 16 & 0,701 & 0,690 \\
\hline Labdapassz U19 & 16 & 0,351 & 0,932 \\
\hline
\end{tabular}

Forrás: Saját szerkesztés 
4. táblázat: A labdapassz feladat elöjeles hibái, korosztályokra bontva

Table4: Self-assessment errors in the passing task, divided into age groups

\begin{tabular}{|c|c|c|c|c|}
\hline \multirow{2}{*}{$\begin{array}{c}\text { Elöjeles becslési hiba } \\
\text { labdapassz }\end{array}$} & \multirow{2}{*}{$\mathbf{t}$} & $\mathbf{2}$ & \multicolumn{2}{|c|}{$\mathbf{9 5 \%}$-os konfidencia-intervallum } \\
\cline { 4 - 5 } & & & Alsó korlát & Felsó korlát \\
\hline U11 & 3,981 & 0,001 & 0,322 & 1,065 \\
\hline U14 & 0,002 & 0,998 & $-0,533$ & 0,534 \\
\hline U16 & 4,067 & 0,001 & 0,334 & 1,069 \\
\hline U19 & 1,508 & 0,152 & $-0,145$ & 0,848 \\
\hline
\end{tabular}

Forrás: Saját szerkesztés. Megjegyzések: $N=16$ minden csoportban, $t=$ egymintás $t$-teszt

(a tesztérték a nulla). $p<0,01 ; p<0,05$

A feladat elvégzésekor cél, a minél több passz elérése a tornapad segítségével. A 3. és 4. számú táblázat alapján megfigyelhetö, hogy az átlag 0,694 tehát az elöjele pozitív, ami felülbecslést jelez, a szignifikancia szint 0,001 , ezért a különbség szignifikáns. Ezek alapján megállapítható, hogy az U11-es korosztályban a labdapassz gyakorlatban, átlagosan a felülbecslés volt a jellemző.

Az egymintás $t$-teszt 3. és 4. számú táblázatai alapján megfigyelhető, hogy az U14-es korosztály adatai szerint az átlag 0,002 pozitív elöjelü, viszont a különbség nem szignifikáns, mert a szignifikancia szint 0,998, így nem mondhatjuk, hogy biztosan magasabb-e a felülbecslések száma.

A 3. és 4. táblázatokról leolvasható, hogy az átlag pozitív előjelü 0,701 értéket mutat. Szignifikancia szint 0,001 , ami szignifikáns különbséget jelez, ezek alapján kijelenthető, hogy az U16-os korosztály labdapassz feladatánál több esetben felülbecsülték a teljesítményüket.

Az ifjúsági csapat labdapassz feladat után kapott adatok alapján, amit a 3- és 4. számú táblázatok szemléltetnek, az átlag pozitív előjelü 0,351 , ami felülbecslésre utal. A szignifikancia szint 0,152 , ami nem nevezhető szignifikáns különbségnek, így nem lehetünk benne biztosak, hogy az átlag eltér a nullától. Ebben az esetben statisztikai szempontból nem mondhatjuk biztosan, hogy a felülbecslések száma a nagyobb.

\subsection{A szlalom feladat felülbecslésének tendenciája}

5. táblázat: A szlalom feladat elöjeles becslési hibái, korosztályokra bontva

Table5: Self-assessment errors in the slalom task, divided into age groups

\begin{tabular}{|c|c|c|c|}
\hline Elöjeles becslési hiba & $\boldsymbol{N}$ & Átlag & Szórás \\
\hline Szlalom U11 & 16 & 0,507 & 0,852 \\
\hline Szlalom U14 & 16 & 0,317 & 0,945 \\
\hline Szlalom U16 & 16 & 0,321 & 0,943 \\
\hline Szlalom U19 & 16 & 0,666 & 0,726 \\
\hline
\end{tabular}

Forrás: Saját szerkesztés

6. táblázat: A szlalom feladat elöjeles becslési hibái, korosztályokra bontva

Table6: Self-assessment errors in the slalom task, divided into age groups

\begin{tabular}{|c|c|c|c|c|}
\hline \multirow{2}{*}{$\begin{array}{c}\text { Elöjeles becslési } \\
\text { hiba }\end{array}$} & \multirow{2}{*}{$\mathbf{t}$} & \multirow{2}{*}{$\mathbf{p}$} & \multicolumn{2}{|c|}{ 95\% -os konfidencia-intervallum } \\
\hline & & & Alsó korlát & Felső korlát \\
\hline U11 & 2,382 & 0,031 & 0,053 & 0,961 \\
\hline U14 & 1,344 & 0,199 & $-0,186$ & 0,821 \\
\hline U16 & 1,363 & 0,193 & $-0,181$ & 0,824 \\
\hline U19 & 3,667 & 0,002 & 0,279 & 1,053 \\
\hline
\end{tabular}

Forrás: Saját szerkesztés. Megjegyzések: $N=16, t=$ egymintás $t$-teszt (a tesztérték a nulla) $p<0,01$; $p<0,05$

Az 5. és 6. táblázatok eredményei alapján az átlag 0,507 pozitív előjelü, így megállapítható, hogy a többség túlértékelte a teljesítményét. A szignifikancia szint 0,031 , a különbség szignifikánsnak mondható, a nullától így biztosan eltér. Kijelenthető, hogy az U11-es korosztály játokosai többségében nagyobb értéket becsültek, mint amennyit ténylegesen elért a feladat végén.

Az adatokat az 5. és 6. számú táblázatok szemlélteti. Az átlag jelen esetben pozitív előjelü 0,317. Az átlag alapján azt mondhatjuk, hogy a felülbecslések száma átlagosan magasabb lett ebben a 
korosztályban, viszont nincs szignifikáns különbség, hiszen a szignifikancia szint 0,199, ami által nem lehetünk abban biztosak, hogy valóban eltér-e a kapott eredmény a nullától.

A serdülö korosztály eredményeit a 5. és 6. számú táblázatok mutatják be. Az U16-os korosztály szlalom feladat után előjeles hibájának átlaga pozitív elöjelű 0,321 ami felülbecslést jelez. Szignifikáns különbség nincs, mert a szignifikancia szint 0,193 . Az adatok alapján így nem lehetünk biztosak abban, hogy a nullától eltér az eredményünk.

A legidősebb korosztály egymintás $t$-teszt eredményeit az 5. és a 6. számú táblázatok alapján láthatjuk. Az átlag ebben a korosztályban is pozitív elöjelü 0,666 , ami átlagosan több felülbecslésre utal. A szignifikancia szint 0,002 ennek köszönhetően szignifikáns a különbség és biztosan eltérő a nullához képest. Összeségében megállapíthatjuk, hogy a szlalom feladatban az U19-es korosztály játékosai átlagosan felülbecsülték a teljesítményüket. A feladatok elött nagyobb értéket becsültek, mint amiennyit ténylegesen elértek a feladatok elvégzésével.

\subsection{A három feladat összesített elöjeles hibájának vizsgálata}

7. táblázat: A vizsgálatban résztvevö korosztályok összesitett elöjeles becslési hibái, feladatokra bontva

Table7: The self-assessment errors of the age groups involved in the study are divided into tasks

\begin{tabular}{|c|c|c|c|}
\hline Elöjeles becslési hiba & $\boldsymbol{N}$ & Átlag & Szórás \\
\hline Dekázás & 64 & $-0,535$ & 0,814 \\
\hline Labdapassz & 64 & 0,376 & 0,899 \\
\hline Szlalom & 64 & 0,373 & 0,901 \\
\hline
\end{tabular}

Forrás: Saját szerkesztés

8. táblázat: A vizsgálatban résztvevö korosztályok összesitett elöjeles becslési hibái, feladatokra bontva

Table8: The self-assessment errors of the age groups involved in the study are divided into tasks

\begin{tabular}{|c|c|c|c|c|}
\hline \multirow{2}{*}{ Elöjeles becslési hiba } & \multirow{2}{*}{$\mathbf{j}$} & \multicolumn{2}{|c|}{$\mathbf{9 5 \% - o s ~ k o n f i d e n c i a - i n t e r v a l l u m ~}$} \\
\cline { 4 - 5 } & & & Alsó korlát & Felsö korlát \\
\hline Dekázás & $-5,256$ & 0,001 & $-0,738$ & $-0,331$ \\
\hline Labdapassz & 3,342 & 0,001 & 0,151 & 0,601 \\
\hline Szlalom & 3,309 & 0,002 & 0,148 & 0,598 \\
\hline
\end{tabular}

Forrás: Saját szerkesztés. Megjegyzés: $N=64=$ egymintás $t$-teszt (a tesztérték a nulla) $p<0,01 ; p<0,05$

A 7. és 8. jelölésü táblázatok a korosztályok sztenderdizálás után összesített előjeles becslési hibáját szemlélteti. A dekázás esetében az átlag -0,535 ami alábecslést mutat, a szignifikancia szint kisebb, mint 0,001, ami szignifikáns különbséget jelez, biztosan eltér a nullától. A kapott adatok alapján azt a következtetést vonhatjuk le, hogy a vizsgáltban szereplő játékosok a dekázás alkalmával hajlamosabbak voltak inkább alábecsülni a teljesítményüket. A sztenderdizálás után összesített előjeles becslési hibák elkövetett elöjeles hibáinak az átlaga 0,376 a labdapassz feladatban, tehát pozitív előjelü. A szignifikancia szint 0,001 tehát a különbség szignifikáns, ami azt bizonyítja, hogy a nullától 99,9 százalékos biztonsággal eltér. Az eredmények alapján azt a következtetést vonhatjuk le, hogy ebben a feladatban a teljesítményeket tekintve hajlamosak voltak a gyerekek inkább felülbecsülni. A becslés során magasabb értékeket mondtak, mint amennyit a feladat végén elértek. Az összesített táblázat alapján elmondható, a szlalom feladatban a becslési hibák átlaga 0,373 , a szignifikancia szint 0,002 , ami alapján elmondható, hogy szignifikáns a különbség és biztosan eltér a nullától. A korosztályokra az jellemző ezek szerint, hogy átlagosan túlértékelték a teljesítményüket a szlalom feladat végrehajtása előtt.

\section{Következtetések, javaslatok}

Az eredmények által levont következtetéseimet tesztekre és gyakorlatokra bontva ismertetem, és adok ennek alapján javaslatokat is. Az egymintás $t$-teszt segítségével arra kerestem a választ, hogy a vizsgálatban résztvevő korosztályokban átalagosan az alul- vagy a felülbecslés mértéke nagyobb a saját teljesítményre adott előrejelzésben. A dekázás feladatában két korosztály, az U14-es az U16-os korosztály esetében volt az átlagok között szignifikáns különbség, ami alapján azt állapíthattuk meg, hogy az említett korosztályok játékosai közt átlagosan az alulbecslésre voltak hajlamosak a dekázás 
feladatában. A korosztályok szerinti sztenderdizálás után összesített adatok is azt a jelenséget igazolták, hogy átlagosan alulbecsülték a dekázási teljesítményüket a gyerekek. A gyakorlati feladatok során a gyerekek alulbecsülték képességeiket, de több esetben kiderült, hogy jobban megy nekik, mint ahogy ők gondolták. A labdapassz feladatban már más önértékelési mintázatok jelentek meg az eredmények alapján. Biztosan két korosztály adataira hivatkozhatok. Az U11 és az U16- korosztályokban volt szignifikáns különbség, ami szerint a vizsgáltban szereplö gyerekek között a teljesítmények felülbecslése átlagosan nagyobb volt. Összességben is elmondható, hogy az összesített korosztályi adatok azt mutatják, hogy átlagosan nagyobb volt a felülbecslés mértéke a labdapassz feladatában. szlalom feladatban az U11 és U19-es korosztályban volt fellelhető szignifikáns különbség, miszerint a gyerekek átlagosan felülbecsülték a képességeiket. Az összesített mutatók alapján kijelenthetö, hogy a szlalom feladatban összességében a felülbecslés volt a jellemző.

A további vizsgálatokhoz érdemes lenne a gyerekekkel egy olyan kérdőívet kitölteni, amely arra kérdezz rá, hogy mennyit gyakorolják az adott feladatokat és ennek alapján más vizsgálati szempontból is elemezni lehetne az önértékelési képességeiket. A gyakorlatokra vonatkozóan a másik fontos tényező pedig az lehet, hogy a feladatot tornateremben is megvizsgáljuk, mert elképzelhető, hogy ott más eredmények születnének, mint ebben az esetben.

Az utánpótláskorú sportolóknál fontos lenne, hogy minél több sportpszichológiával kapcsolatos beszélgetéseken vegyenek részt, ami által tisztábban láthatnánk a felmerülő gondokat és nem utolsó sorban a gyerekek objektívebben tudnák megítélni a saját képességeiket. A pszichológiai segítség mellett az edzőknek is többet kellene kommunikálni a gyerekekkel, mert időben megelőzhető lenne a kedvezőtlen önértékelés kialakulása.

\section{Összefoglalás}

A fő célkitűzésem a kutatással kapcsolatosan az volt, hogy a saját tudás túlértékelésének tendenciáját vizsgáljam meg utánpótláskorú labdarúgók körében. A kutatás alapján az állapítható meg, hogy a labdarúgás egyes feladataiban eltérő önértékelési tendenciák jelentek meg. A vizsgálat eredményei által elmondható, hogy a dekázás feladatában átlagosan az alulbecslés volt a jellemző, míg a szlalom és a labdapassz gyakorlatban a felülbecslés, ami a gyerekek önértékelési képességére utalt.

\section{Irodalomjegyzék}

Boud, D., Falchikov, N. (1989): Quantitative Studies of Student Self-Assessment in Higher Education: A Critical Analysis of Findings, Spinger, Higher Education,Vol. 18, (No. 5.) pp. 2.9. Conroy, D., Cassidy, C., Elliot, A. (2008): Prospective Relations Between $2 \times 2$ Achievement Goals and The quality of sport training, Revue internationale de psychologie sociale, p. 109-134.

Gyömbér N., Kovács K. (2018): Fejben dől el, Sportpszichológia mindenkinek, Bp. Noran Libro, pp.3436.

Gyömbér N.-Kovács K.- Ruzits É. (2016): Gyereklélek sportcipőben, Bp. Noran Libro pp. 55-58. Fogarty G., Else D. (2011): Performance calibration in sport: Implications for self-confidence and metacognitive biases, International Journal of Sport and Exercise Psychology, pp.41-57.

Horgan D. (1992): Children and chess expertise: The role of calibration, Springer, pp.44-50.

Kovács K., Nagy B. (2015): A sportolás hatása a kiskamaszok énképére, szorongására és megküzdésére, Különleges Bánásmód, 3. pp. 2-13.

Orosz R. (2010): A sporttehetség felismerésének és fejlesztésének alapjai, Magyar Tehetségkutató Szervezetek Szövetsége, pp.52-56.

Robins, R., Trzesniewsk, K. (2005): Self-Esteem Development Across the Lifespan, Current Directions in Psychological Science 2005 14: 158, pp. 2-5.

Sallay V., Martos T., Földvári M., Ittzés A. (2014): A Rosenberg Önértékelés Skála (RSES-H): alternativ forditás, strukturális invariancia és validitás, Mentálhigiéné és Pszichoszomatika 3, pp. 260-266. 